\title{
4 \\ Banter, catcalls and racial intimacy
}

Io nun capisco, ê vvote, che succede

E chello ca se vede nun se crede! Nun se crede!

È nato nu criaturo niro, niro.

E a mamma 'o chiamma Giro,

Sissignore, 'o chiamma Giro.

Seh! Gira e vota seh!

Seh! Vota e gira seh!

Ca tu 'o chiamme Ciccio o

'Ntuono

Ca tu 'o chimme Peppe o Giro

Chillo 'o fatto è niro, niro

Niro, niro comm'a che!
I don't understand what's going on these days

And you wouldn't believe it either.

A baby was born - all black.

And his Mum calls him Ciro,

Yessir, she calls him Ciro.

You can twist it and turn it,

Twist it and turn it how you like,

Whether you call him Ciccio or Antonio,

Whether you call him Peppe or Ciro It's black times we're in

As black as can be!

Verse 1 and chorus of 'Tammuriata nera' (1944), music by E. A. Mario, lyrics by Edoardo Nicolardi (translated from Neapolitan by the author) ${ }^{1}$

The extract From the song 'Tammuriata nera', reproduced above, speaks Allied soldier towards the end of the Second World War. We can assume that the soldier arrived in the city with the Allied troops after 1943, following the Italian surrender and the Four Days of Napoli, when members of the Italian Resistance grouped together with town folk to rise up against the German troops occupying the city. From Napoli, the Anglo-American troops moved north and, eventually, defeated the Germans in 1945. But the Allied presence in the city continued until 1947 , and then was reconfigured through the imposing presence of the NATO 
base, situated next to Lake Patria. Until the 1980s arriving in the city by plane involved flying into a base, often in the company of military personnel, and after British Airways took over the airport a segregated area was maintained solely for military use. As local people told me, US, French and Italian bombers took off from Capodichino Airport during the First Libyan War in 2011, causing the ground to shake as they departed. My research participants also mentioned the foreign troops based locally, using the loose term 'the American soldiers' to describe them. They talked about them starting fights with pacchisti around Piazza Garibaldi and I met people who had been in relationships with soldiers based in the city.

'Tammuriata nera' dwells upon the birth of non-white 'occupation children' in Napoli, a topic that has been the subject of a number of novels, war memoirs and academic studies about postwar experience in Europe and the USA (Cassamagnaghi 2009; Fehrenbach 2007; Malaparte 2010; Pezzarossa 2013). The birth of non-white children during wartime was seen as the ultimate emblem of the problem of uncontrolled female licentiousness and the taboo of miscegenation. In a white-supremacist, patriarchal society these war romances were subject to far greater social sanctions than those involving white GIs, which were also common. This was because the women were seen to have transgressed on two grounds: against their sex by entering into a sexual relationship outside marriage, and against their race by engaging in intimate relations with a man who was not white. 'Tammuriata nera' has been celebrated as an antiwar song, performed at urban concerts and village feste, and enjoyed by subsequent generations of Neapolitans. However, James Senese, the famous Neapolitan blues musician and one of the generation of mixed-race war children born in the city, has asked people to stop celebrating the song as a local cultural treasure, but instead listen more carefully to what the lyrics say about the immorality of the mother and the ambivalent status of the child (Quagliata 2019).

Pezzarossa has argued that the negative treatment experienced by these children in the postwar period connected scientific racism and fascist ideologies to the forms of cultural racism that, particularly, black migrants experienced when they started arriving in Italy (2013: 274). My fieldwork was replete with obsessive talk, sometimes directed at women and sometimes emerging in discussions between Neapolitan and migrant men, about women who spent too much time in public spaces such as street markets, where their presence was not respectable and was potentially threatening to their honour. The status of women in public spaces was connected to long-standing notions of how to maintain 'sexual preserves' in towns and villages in the Mediterranean - by controlling 
the behaviour of women in public spaces (Harding 1975; Reiter 1975) - but also to the ideological underpinnings of empire, white supremacy and militarism (Ware 2019). This pointed to the centrality of sexuality in social, political, economic and cultural relations, where women's sexual behaviour has been closely governed in ways that are gendered, racialised and classed (hooks 1994; Rubin 1975; Ware 2015). The differential experiences of the women in my street market sites - black women, white Neapolitan women, those working in the market or those passing through - revealed key insights about interconnected patterns of sexual conventions and racialised domination in Napoli. These conventions uncovered a melancholic recollection of colonialism and US military occupation - that continued to demarcate the city in subtle ways - and laid the groundwork for negotiating and managing contemporary fears around racial intimacy.

Paranoias about the threat to local 'sexual preserves' were articulated through darkly humorous speech genres - that I refer to as banter and catcalls - that formed an important part of the performance of locally hegemonic masculinities in the everyday life of the street (Connell and Messerschmidt 2005; Harding 1975; Reiter 1975: 58). Elsewhere in the book I have talked about humour as something that both challenged power - to defuse tension or imagine alternative solidarities - and functioned in complicity with power to abuse, silence and oppress subaltern groups of people (Bakhtin 1984 [1965]; Passerini 1987: 67126; Smitherman 1977, 2006, 2007). In the case of talk about the status of women and the threat of racial intimacy, joking practices were much more likely to shut down the possibilities for a transcultural Relation. Banter between men, and catcalls directed at women, served to make space for ritualised insults to take place within a playful context in such a way that things were usually prevented from escalating out of control (Hewitt 1986: 170-187). These performances revealed a reality of locally hegemonic masculinities where violence was potentially justified as a reaction to the humiliation of economic austerity and the lack of opportunities for employment. They also showed how a local hierarchy of masculinities existed that occasionally implicated both Neapolitan and migrant men in its activation (Connell and Messerschmidt 2005: 845-847). However, whilst migrant men could sometimes participate in banter and catcalling, the participation of women in this sort of talk was much more contingent. Banter and catcalling worked to fix the status of women and control the threat of racial intimacy as part of displays of militarised, almost exclusively white, and masculine dominance. 


\section{Banter with women working in street markets}

The feminist literature, cited in the last section, about the management of sexual preserves in the Mediterranean, was based on research conducted in the first half of the twentieth century. This research showed women to be largely absent from, or only able to pass through, public spaces on their way back to the private sphere of the home (Harding 1975; Reiter 1975). Street markets in Napoli of course became increasingly diverse, fluid and contested spaces following the end of the Second World War. Nonetheless, it was still significantly less common to see women working as street vendors when I was doing research in 2012. Alessandro, of Peppe's Bags, had run a stall at Poggioreale market for the last decade. Like many other vendors, he and his family had started out with a small warehouse in the centre of Napoli and then later took on the stall to make more money. There were many things about running a market stall that Alessandro struggled with. He and his goods were at the mercy of the weather and he always had to wear his oldest and most casual clothes. Above all, he didn't like the market because he thought stall-holders were common and rough: 'they shout', he told me, 'and they use nasty words'. In fact he didn't ever let his wife work on the market stall. His wife ran the family shop, as he felt that markets, unlike shops, were unsuitable working environments for women, and so she was safer there. He believed that the bawdy and ribald language that often dominated market life was unsuitable for women to hear, precisely because it was often irreverent and contained sexual undertones.

Nonetheless, women did work on market stalls, such as Titti of the Eddy Pell stall at Poggioreale market, who worked alongside her husband. Whilst she often worked in the family shop on her own, I noticed that when she ran the market stall her dad was usually there as a chaperone. The few West African women who had market stalls selling clothes, fabric and jewellery at Via Bologna market, or sold hot and cold meals and refrigerated drinks from hampers that they dragged on trolleys around Piazza Garibaldi, worked alone or alongside other West African women. Comfort had run a market stall around Via Bologna and Piazza Garibaldi since she had arrived in Napoli from Nigeria twenty years previously. She was the first black woman to run a stall in the area and had learnt to be tough and uncompromising in order to safeguard her position in the market. She worked alone, although her Nigerian friends often came to visit her. When we were first introduced, she had a spot right on the corner of Via Bologna, one of the most lucrative points in the market for taking advantage of the footfall that passed by the market going from the train station to the city centre. She 
was furious because she felt that the unlicensed street vendors on the corner of the market were moving in on her spot. At the time, many of these men were Guinean nationals, newly arrived in the city via the Mediterranean crossing and awaiting the result of asylum applications. She was also deeply suspicious of the other Nigerian women who had set up stalls selling wax cloth, jewellery and accessories further up the market. She told me that she had called the police on them, claiming they were selling contraband and hadn't paid all their taxes. She was, however, cordial to the Senegalese, Guinean and Nigerian women who wheeled mobile stalls up and down the market selling food, snacks and hot drinks, often buying rice and stew from them for her lunch.

Comfort was comfortable expressing frustration, rage and a sense of unwelcome competition when it came to other migrant vendors, both men and women. These dynamics changed markedly when it came to interacting with the Neapolitan men working in and around the market. With them, it was important for Comfort to be able to engage in aggressively masculine and ambivalently humorous performances of banter in order to safeguard both her spot and her status. The pacchisti particularly liked to tease her by calling out her name and trying to tickle or embrace her. She would smile at them and then hit them soundly, telling me, 'they're funny but they're not good people'. On one occasion, one of these men came to greet her, reaching through the curtain of clothes hanging round her stall and calling out.

Man: Comfort, how are you?

Comfort: Good, and you? How's work?

Man: I'm always good when I see you, Comfort. You work better in summer don't you? The winter is always slow ... How's your work going today?

Comfort: [making a face and rubbing a thumb and two fingers together] Need money.

Man: Comfort, if you need money you just need to ask ... How much do you need? A thousand, a hundred? I have [rifling through pockets] two euros.

Comfort: Give me! I need to buy some water.

Man: You need water? You just need to ask! I will go and get it for you ...

The man trotted off, leaving Comfort looking slightly bemused. He was never to return.

She watched him depart with a perplexed expression on her face whilst their interaction became a source of amusement for the men with stalls around her. The man had put on a mocking pretence of male chivalry, pretending to play the 
role of the male provider and family man. His offer of money, and even the offer to get her a bottle of water, were not sincere, but a jokey performance intended to produce a parody of gender relations that sent Comfort up as a woman who was not respectable.

On another occasion, Comfort sought to include herself in a discussion about the possible closure of Via Bologna with Gennaro, Alfonso and Omar. As she approached the men, one of the pacchisti tried to grab her round the waist, receiving a number of thumps in return. She turned to Gennaro and joked.

Comfort: That guy's 'ricchione [homophobic Neapolitan word], innit!

Gennaro: Hey there now!

Pacchista: What, you're even wearing gloves? So you offer a full service then? [eruption of laughter amongst the Neapolitan men]

Comfort: [confused] That's to not get cold! To not get cold!

The conversation about the market went on for a little while and then Comfort returned to her stall. I asked Gennaro what 'full service' meant and he told me that the man was calling her a sex worker. Gloves were a slang word for condoms and a 'full service' was the term used to describe a sex worker prepared to offered full intercourse.

Me: Do you think she understood?

Gennaro: I don't think so, or she would have given him a good kicking!

Comfort had learnt to try and defend herself against this sort of treatment by acting up to the local figure of u'maschiolona - a woman who affects the mannerisms and forms of banter of a local tough guy. Her loud proclamation of 'That guy's 'ricchione, innit?' showed how homophobic accusations were an important way in which locally hegemonic masculinities were asserted within the context of Neapolitan pavement interactions. However, it was clear, from the fact that Comfort's body remained vulnerable to abuse and aggression, that these appropriations of masculine banter were highly contingent for her. Comfort's efforts to include herself in key discussions about the market, and defend herself from being physically assaulted by the men working there, resulted in a further reinforcement of her status within the political economy of sexual hierarchies in Napoli, where black women were stereotyped as sex workers. The men's language was both comic and violent, referring grotesquely to intercourse and prostitution in order to fix Comfort's body around exclusionary markers of race, 
gender and sexuality. In Napoli, language practices of inclusion and exclusion were constructed through a hierarchical linguistic dexterity with both Italian and Neapolitan, as well as locally understood meanings about sexual worlds, femininities and masculinities. As a speaker of Italian as a second language, Comfort's lack of knowledge with Neapolitan sexual slang rendered her unable to realise fully what was being said in order to try and put the man back in his place. The man who spoke knew she would be unlikely to understand and took advantage of this to have a laugh at her expense, with the receptive complicity of the other men present.

The white Neapolitan men in street markets subjected Comfort to such frequent public humiliation because she was a lone businesswoman, but also because she was a black woman. In general, black women, particularly if they were Nigerian or might be seen to be Nigerian, were subjected to intense racist and sexist abuse on the streets in Napoli. Frequently it was implied, or asserted, that they were sex workers. This stereotype had emerged in Italy from the 1980s, as a horrific trade in sex trafficking from West Africa had developed (Okojie 2009: 150-151). In 2017, it was estimated that 80 per cent of Nigerian women arriving in Italy by sea were being trafficked into sex work (Kazeem 2017). The kinds of banter Comfort took part in, and had imposed on her - from the everyday attacks, whereby she was tickled and called by name as she worked, to embarrassing and confusing role-plays of gender normativity, to barely veiled accusations that she was a sex worker - allowed the pacchisti to reinforce local sexual conventions that were formed of interconnected, racialised, gendered and militarised patterns of white-supremacist patriarchy. Local convictions about feminine respectability interacted with historic tropes about black femininity and hypersexuality where the present replicated patterns of domination between female slaves and slave masters, or colonised women and colonial soliders. Comfort's vulnerable status in the street markets was infused by the reality of Napoli's situation on the edge of the necropolitics being enacted in the Mediterranean, where women like her appeared to be outside humanity and disposable (Mbembe 2019).

\section{Banter about the women back at home}

When women were not present they were conjured up through the banter between men about each other's womenfolk. This allowed the men to explore ideal types of feminine behaviour within a heteronormative social order that was trying to come to terms with the fact of migration. One of the first things that Salvatore 
said to me about Ibra was, 'Do you know that Ibra has four wives?' Ibra rolled his eyes and crossly told us, 'It's not true!', but smiled to show he wasn't really angry. Salvatore turned to me and told me that it was true that, 'these Senegalese men have more than one wife'. Salvatore's joking banter about polygamy highlighted the different sexual roles within Islamic and Judaeo-Christian custom as part of an attempt to embarrass Ibra and goad him into a confrontation.

Of course, the fact of my being there to witness such discussions problematised the comic exchanges taking place. To some extent they were happening for my benefit or with an awareness as to my presence. One day I went to do some fieldwork at Via Bologna market. It was raining and I found Gennaro, Serigne and Riccardo chatting together in Riccardo's shop. At one point in the discussion, conversation turned to relationships and the games men played to avoid having to make formal commitments to women. Riccardo offered the example of a man he once knew - a committed bachelor - who used to say, 'If I want a glass of milk why do I have to buy the cow?' The men cracked up laughing. It was only at this point that they noticed my pained expression and then awkward justifications and declarations ensued. Gennaro told me that women had only one sin: that of having betrayed Adam. Serigne nodded in approval and Gennaro commented that even Serigne, as a Muslim, knew this was the truth. Then the men started telling me how amazing their womenfolk were. Gennaro told me that there was nothing as beautiful as the connection between two partners, and recalled how his wife had a sixth sense about various situations he had been in over the years that had saved him literally from ruin. Riccardo told me he had a son and a daughter. His son had a degree and worked as an engineer. His daughter was a housewife but she was much sharper than his son. 'I vote women', he told me, making a fist with his right hand and raising his arm in the air.

They then started to joke about the difficulties of talking to women. Gennaro complained that men could never say the right thing in an argument, whether they talked or remained silent. But he thought a woman's silence could be terrible, and her anger even worse. He stated that women ruled in the home and they were tough, even though it didn't always seem so. Gennaro then commented that African wives were more oppressed. He said that his friend Moussa had told him they beat their women in Africa to keep them under control. Riccardo disagreed, saying that whatever it looked like from the outside, the women were always in charge. He said that the mistake women had always made was to spend so many years hidden behind their men. Serigne interjected to say that it wasn't true that all African men beat their wives. Gennaro responded that his friend Moussa had told him; he didn't make it up himself. 
The initially unselfconscious banter between Gennaro, Riccardo and Serigne served to explore the possibilities of a general consensus about the role of women in relationship to men. In trying to justify Riccardo's misogynistic joke about milking cows they only further clarified a series of sexual conventions about women as wives, belonging in the home and existing only in relationship to their husbands. In their justifications they integrated historical beliefs and cultural practices that were both secular and religious, formed of the interconnection of ancient forms of patriarchy, Abrahamic religion and the transformations that had come about in the relationship between public and private, self and Other, from modernity onwards. They playfully joked about the limits of the power that men had over women, with Gennaro positioning African husbands as more violent within the context of a racialised distinction between white male civility and black male savagery. When Serigne challenged him, Gennaro denied responsibility for his comments by stating that an African friend had told him these things, so they must be true. Their banter established a local sexual order where communities did not meet across racialised boundaries outside the public sphere of the street market. The maintenance of these sexual and racial preserves helped to reinforce the notion that, at home, each man was in charge of family life, and the types of control he chose to exercise there were reflective of the differential statuses of particular racialised and culturally inflected masculinity. My presence, in itself disruptive of local sexual conventions, forced them to justify the things they were saying but didn't effectively dismantle the ways in which they spoke about women and their social status with regard to men.

\section{Catcalling foreign women}

Catcalling and sexual harassment are, of course, universal phenomena, and happen across national, racialised and classed contexts. As elsewhere, the way catcalling worked in Napoli was connected to racialised tropes about femininity that had local and global resonances. Catcalling connected local memories of implication within colonial and military dominations to the lived reality of contemporary migration. As I have already discussed, black women were violently interpellated as sex workers and asked how much money they wanted to earn in return for sex. Women with blonde hair and light colouring would hear 'Hey Polish' or 'Hey German' muttered at them as they passed by. These kinds of specific ideas about women, defined by different racialised, ethnic and national stereotypes, necessitated a multilingual approach to catcalling that was typical of daily life on the city's pavements. The proficiency of this multilingual catcalling 
opened a window onto Napoli's history and contemporary reality as a crossroads of different cultures and people (Chambers 2008) - migrants leaving and arriving, merchants, foreign militaries and rulers - that had engendered myriad creolising encounters in complex and improvisational situations of inequality and subordination.

One day, whilst I was doing fieldwork at Ku's stall, a young Neapolitan man came to sit on an empty plant pot near us. He introduced himself as Luca, the nephew of the Neapolitan street vendor selling CDs opposite Ku's stall. He told me that he was a builder and had previously been working to waterproof the region's road tunnels, but had just lost his job. He complained that he had nothing to do, and no money, so was hanging out in front of the station to waste some time. As we sat there, he periodically called out 'konnichiwa' to East Asianlooking women who walked by us, 'Madame' to West African-looking women, and 'Uè bella' ('Hey pretty') to European-looking women. He then turned to me and said, in Italian, 'Aren't our Italian women beautiful though?'

In this episode Luca coded women within a racialised hierarchy of feminine beauty, where 'our' (belonging to Neapolitan, male) women were at the top of the scale. The pleasure he derived from catcalling the female passers-by was clearly heightened by the discomfort and dirty looks he received in response. His performance of masculine domination appeared to salve the frustrations he expressed at the beginning of our conversation about being out of work. It was part of the way in which he derived power in a situation where he felt his own status to have been damaged by the lack of locally available employment. Economic austerity was articulated as a threat to his masculine pride and offloaded onto women in the form of abusive and threatening talk.

On another occasion in the summer, I was taking the Circumvesuviana train back down the coast from Napoli to spend some time with my family in Vico. I entered a compartment that was already filling up with tourists and Neapolitan beach-goers. Getting on just in front of me was a South Asian family, dressed elegantly for what seemed to be their day off. There were two couples, and the women were wearing shalwar kameez. Both were also wearing hijab and one of the women wore a niqab. They had three young children in pushchairs, which they positioned in the aisles as they sat down next to their husbands. A teenage boy, sitting in a large and boisterous group behind me, turned to his friends and joked, in Neapolitan: 'The terrorists are here!' I turned to stare angrily at him as his friends laughed. He ignored me and repeated, 'The terrorists are here!' The train continued to fill up with more tourists - judging, by their accents, from America, Northern Europe and Japan; middle-aged Ukrainian women 
in groups; and Bangladeshi and Senegalese street vendors weighed down with plastic sacks of merchandise and cardboard boxes to make up into temporary market stalls at the entrances to the beach resorts of the Amalfi Ccoast. The boy spoke again, 'Can I say something? It looks like the foreigners here are us.' More giggles and murmurs of assent erupted from his group of friends. As the train set off, the group of teenagers behind me started playing tech house from one of their mobiles, and many of the tourists started chatting animatedly to their travel companions. English, Spanish and Japanese could clearly be heard mingling with Neapolitan, Ukrainian, Wolof, Bengali and so on, set off by the tinny beat issuing forth from the young Neapolitan's phone. The multilingual babel of people speaking with, and across, each other sparked something off for the young man, keen to entertain his receptive peer group further. He turned to a young American woman and asked her, in accented English, 'Where are you from?' Without waiting for her reply he told his friends, in knowing tones, 'She is a beautiful girl.' Then, to a young Spanish woman, he said, 'Como estas?', followed by 'Arigato!', presumably for the benefit of a group of Japanese tourists on their way to Pompei. A young American woman suddenly exclaimed, ' $\mathrm{Oh}$ my God!', in response to something her friend had said. The boy immediately mimicked her, shouting 'Oh maaaaaaaaaiiiy Gooooood! It is wonderful!', in drawn out tones. His friends laughed hysterically. The group exited the train a few stops after this outburst and the hum of conversation resumed as we continued with our journey.

This episode provided further insights into the different status of women in Napoli on the basis of the ways in which they were both racialised and classed. The performance of talking about the South Asian family - within their earshot and using recognisable racist stereotypes about Muslims, but in a thick dialect that was designed to be deliberately incomprehensible and so vaguely threatening jarred starkly with the effort the young Neapolitan made to showcase his linguistic aptitude in the languages of the privileged and wealthy female tourists. The South Asians were described as terrorists because of the hijab the women in the group were wearing. This drew on widespread Islamophobic ideas whereby the trope of the oppressed and veiled Muslim women symbolised concerns about the threat of terrorism to western society (Rashid 2016). The flirtatious language invoked with regard to the female tourists was of a different register. Being able to speak English or French to the visiting young women connected the young Neapolitan men to the upward mobility that the women represented. But the sharpness in the young man's mockery on the Circumvesuviana also revealed the 
fraught combination of resentment, attraction, shame, cool and uncool inherent in such interactions. Hierarchical 'language attitudes' (Smitherman 1977) were in place that allowed the young man to use language in a simple way as a tool of oppression against the group of South Asian Others on the train. But at the same time, his interactions with the tourists showed how aware he was that his own language and culture had historically marginalised him.

Migrant men were also often on the receiving end of catcalls. The catcalls that migrant women were subjected to were not unconnected to the jokey forms of address that Neapolitan men gave out to migrant men, such as 'Oi, blondie!' (to black men) and 'myfren' ('my friend'). These calls were often directed at men unknown to the callers themselves and were part of the same performances of locally hegemonic masculinity through which gendered and racialised power dynamics were asserted in daily life. Catcalls mostly sought to police and maintain sexual conventions that were heteronormatively heterosexual, but not exclusively. The catcalling of migrant men by Neapolitan gay men, who would not have been so bold as to harass straight Neapolitans, highlighted the vulnerability of migrant men within the local political economy, and the racialised dynamics of gendered control. It would definitely not have been safe for gay Neapolitan men to approach straight Neapolitans in the city in this way. On one occasion I saw a local man make an obscene gesture and wiggle his tongue at a black man walking in front of me with a female companion. A few of my Senegalese male friends also told me they had been followed home after nights out by men in cars seeking to pay them for sex. I once spent an evening at the stall of one research participant locked in an awkward interaction between him and a Neapolitan man who regularly came to the place where he put his stall out looking for him. The fact of the Neapolitan man's attraction was never expressed explicitly but my informant felt it strongly enough that he had avoided repeated invitations to meet up outside of work. In these encounters the greater sexual privilege lay with the gay Neapolitan men, and the migrant men were vulnerable because of their economic marginalisation and, often, undocumented status. The fact that gay Neapolitan men were more empowered than migrant men revealed a really important truth about the forms that gendered violence could take when cut through with race and class. These practices were illustrative of the ways in which local masculinities, and the exercise of gendered violence, existed within a hierarchy of masculinities where being oppressed and oppressing someone else could meld together, transform and mutate depending on the circumstances (Connell and Messerschmidt 2005: 845-847). 


\section{Policing racial intimacy}

Banter and catcalling were also used to comment aggressively on instances of real and suspected racial intimacy between white Neapolitan women and black migrant men in public spaces. These interactions most clearly revealed the ways in which Neapolitan male power was founded on the maintenance of local sexual preserves, and the gendered domination of both migrant men and women. Sometimes these violent instances of talk called explicit attention to these connections between past and present. A Senegalese man I spoke to told me that his friend's girlfriend was once subjected to a loud tirade in the street by a group of young Neapolitan men, who accused her of 'liking black men'. Another Neapolitan woman told me that once she was at the beach with her Senegalese partner of ten years and she got called a prostitute who 'liked these Americans' by a middle-aged Neapolitan man as he sat tanning on his lounger. The public sighting of racial intimacy signalled a critical breakdown of Neapolitan female morality that threatened Neapolitan male power. This threat was managed through aggressive verbal attacks that sought publicly to humiliate the woman and threaten her partner.

Other times, these forms of male control were exercised in more subtle ways. One late Sunday afternoon I was standing with Modou on the pavement next to his stall. The designer wares glimmered in the light of a street lamp, set off by the white sheet arranged in a neat rectangle at our feet. It was cold and there weren't many people about so I did notice the intense look sent our way by two Neapolitan men as they passed by. I pointed it out to Modou and we both laughed, imitating the stare we had received. It was only later, when I was at home transcribing the recordings made during that afternoon, that I realised the significance of this look. This is what I heard on the digital recorder.

Me: I need to go to the bathroom.

Modou: Ok.

Me: I'll just go to the bar ... I'll leave everything here.

Modou: Ok!

[I leave and a few seconds pass by.]

Voice of Neapolitan man: So is that your stuff?

Modou: No ... she - England.

Voice of Neapolitan man: Oh ok. So that's not your stuff then?

Modou: No, no ...

Unlike English, Romance languages such as Italian and Neapolitan do not require a subject pronoun to indicate who is doing the action of the verb. The gender of 
the surrounding nouns and adjectives in the phrase, as well as the context of discussion, generally make the meaning clear to the speakers involved. Here, 'is that' was a translation of 'è', the third person conjugation of the verb 'to be'. The object of the sentence was 'stuff', or 'roba', a feminine noun. On the surface the Neapolitan man could easily have been asking about the wares on Modou's stall; but Modou's response unequivocally demonstrated that he understood the man was talking about me. He was asking if I was romantically involved with Modou, and Modou was very keen to emphasise that I was not. Moreover he let them know that I was not local, but a foreigner whose honour they potentially had lesser claims over.

The next time I saw Modou I asked him if he remembered who the men were and what they meant by 'your stuff'. Modou said he had no recollection of the exchange. Marco, a middle-aged Neapolitan friend of Modou, was hanging out nearby and overheard our discussion. He confirmed that the disembodied voice on the recording was most probably talking about me and, looking at me curiously, asked if I was offended. I told him that I wasn't but that this was interesting for my research project. He became defensive, saying he couldn't see why it was interesting. He told me it was 'normal for Neapolitans to act that way', and gave me an example of something else that had happened between himself and Modou. One time he had come to say hi to Modou and found him chatting to a Neapolitan woman. He playfully hit Modou and the woman said, 'leave him alone or I'll have ya'. He asked her if she was his girlfriend and she replied that she wasn't.

Modou and I had transgressed racialised sexual conventions in Napoli by being seen together in public space. As Marco told me, the reaction of the unknown local Neapolitan men was normal and we didn't have the right to expect otherwise. The crude, jokey warning given to Modou in Neapolitan about me possibly being his 'stuff' served to re-establish a localised hierarchy of male power that was white and Neapolitan. As mentioned elsewhere, the use of Neapolitan often corresponded to a masculine gangster or guappo stereotype and so functioned as a form of posturing, aggression and intimidation. To emphasise the aggressive, and yet banal, nature of these pavement dynamics, Marco provided an example of how he himself had taken part in a similar moment of jokey sexual policing between Modou and another white woman. This was revelatory of the ways in which both complicity and oppression worked side by side in the maintenance and reinforcement of local sexual conventions.

This episode also made me understand how potentially risky it had been for Modou to allow me to come and do research with him, and how carefully he had worked to negotiate my presence, for example with his assertion that I was 
English and not local. Modou would often jokingly tell curious passers-by that I was his sister. On one occasion this clearly annoyed a Neapolitan friend of Modou who said to us, 'Your sister? She's white!' When I first met Carlo, he asked if I was Modou's girlfriend and Modou again claimed that I was his sister. I told Carlo about my project and he responded, 'What are you researching? The bog?' Carlo's use of grotesque comic and abusive language served here to overturn Modou's joking claim of kinship and put my honour back into question, re-evoking the potential of humorous language to function in complicity with oppressive power dynamics.

Salvatore, who worked near to the spot where Ibra set up his mobile market stall, was another Neapolitan research participant who was overly concerned with the maintenance of female honour and the threat posed to it by the presence of black men. One day Salvatore decided to broach this topic with me. He complained about a group of young female students who lived in one of the apartments in the block where he worked as a doorman. When he went to knock on their door they would invariably answer in their pyjamas and invited him in for a snack. He had always thought their behaviour was scandalous. Another female friend also often asked to use his personal toilet when she passed by and he was horrified that she never locked the door or asked him to guard the door outside. 'You never know what can happen these days', he told me, his brow furrowing with concern. He explained that a man might pretend to be a friend to a woman but, as soon as he got the chance, would attack and rape her. At this point our conversation was interrupted by a young couple on their evening stroll. The Senegalese man stopped to greet Ibra in Wolof while his Neapolitan girlfriend waited for him.

Salvatore: [loudly, to me] You see that?

Girlfriend: [to her boyfriend] Baby, I have to pee!

Salvatore: Look! She even says that she has to piss!

Salvatore continued talking to me, explaining that women needed to be even more careful when they were with black men, because they were so physically strong. I pointed out that Ibra was actually slighter and shorter than him, but he said that he was only talking in general. He explained that black men were stronger than other men so if things started to get intimate between a white woman and a black man, and the girl decided she didn't want to have sex, the man could easily still force her. He told me, 'only a rifle would stop him then. Not a pistol. You would need a rifle.' Salvatore's astonishing pronouncement called to mind the idea of the 
shotgun wedding, a historic term used to describe a marriage that comes about because the bride has fallen pregnant. First, the image of the rifle evoked the idea of feminine honour that had been brought into question by improper sexual relations between men and women outside marriage. Second, the rifle evoked a colonial image, redolent with ideas of safari and big-game hunting, that painted black masculinity as over-sexualised, irrational and dangerous to Neapolitan female honour. This connection had not occurred to Salvatore naturally. Rather, it was formed of racist tropes about black masculinity that arrived in Italy, first via colonialism and American mass culture in the early twentieth century (Giuliani 2013: 62), and second through the intimate relationships that flourished between black GIs and Neapolitan women during the war. This episode showed the ways in which these ideas were reactivated by the arrival of black men arriving in Italy from Sub-Saharan Africa since the 1980s.

Salvatore's paranoia about the threat posed by black migrant men to Neapolitan female honour arose on a number of other occasions. He would frequently raise this topic by picking fights about sex with Ibra and the other Senegalese men who had market stalls near to where he worked. Often the conversation started with Salvatore accusing his Senegalese colleagues of leading incomplete and unnatural lives, far from their families, and focused only on making money and surviving. Ibra would usually retort that, 'Italians all get cheated on. Just smoke. Just eat. Just do fiki fiki.' Usually he would start cracking up towards the end of such diatribes and escape from the Neapolitans' exaggerated expressions of offence and raised fists. He would never retaliate physically. The three men's dispute around having sex, or doing 'fiki fiki' as they called it, revolved around the physical and moral structuring of their masculinities. Mimmo, a local shop owner, proudly told Ibra that, 'yes! Italian men eat three times a day and do fiki fiki three times a day!' Ibra retorted that this weakened a man and could lead to his death. To illustrate this he wove around the Neapolitan men, limping, to illustrate their physical debilitation through excessive coitus. Salvatore responded sniffily that male virility actually originated in the knees and if men didn't have enough sex they would weaken themselves at the skeletal level.

These humorous discussions about male sexual prowess represented a somewhat safer way for the Neapolitan and Senegalese men to negotiate the racialised and gendered tensions that existed between them. However, the threat of racial intimacy was a constantly lurking undercurrent in their interactions. For the Neapolitan men it was incomprehensible that the married migrant men sincerely intended to wait faithfully to return to their wives in Senegal. 
Salvatore: [to Ibra] When are you gonna have sex? In ten years time?

Mimmo: Why don't you take an Italian woman?

Ibra: Italian woman not the same.

Mimmo: [offended] Why's that?

Salvatore: Look. In life it's important to eat, work and do fiki fiki. But you just work and eat!

Ibra: [smiles] Look, I'm Muslim. We can't do sex outside marriage.

Salvatore: I think Ibra is gay ... Ibra, you gay?

Ibra ignored him and went to reorganise some of the hats on his stall. Mimmo came over to stand behind his bent form, holding his waist.

Mimmo: Ibra be careful when you bend over or else I'll punish you!

[Ibra jumped up in shock and anger, moving out of Mimmo's reach.]

Mimmo: [regretfully] Look how pissed off he gets! Come back Ibra! [to me] Ibra gets so angry when we joke with him like that ... even if we just walk around behind him ... he gets angry and says 'Mimmo! Don't do that! You're no good!'

[Mimmo shrugged and goes back into his shop.]

Salvatore: You're wrong Ibra. It's normal to have sex.

Ibra: Look. It's fine.

Salvatore: [to me] Other Senegalese friends of mine tell me that when they go home to visit all they do is have sex. They go back to make a son they never see. It's not right.

Salvatore: [to Samba, a Senegalese street vendor who had just arrived] Do you like Italian women?

Samba: [holding up his hands] I'm Muslim. I can't do illegal sex.

A number of key themes emerged in the men's bantering about sex. First, it was made clear that ideal Italian or Senegalese masculinities were produced through the way men were seen to exercise their sexuality. Male prowess was constructed either through the practice of regular intercourse or through the exercise of self-control, discipline and restraint. This second vision of masculinity was connected to the Islamic principles that governed relationships between men and women. Catholic dogma did not form a counterpart to the argument the Senegalese men made about 'illegal sex'. Instead, the Neapolitan men made use of hegemonic ideals about the virile family man, a stereotype that emerged under fascism (Giuliani 2013: 63; Sabelli 2013: 88), as a way of accusing the 
Senegalese migrants of not fulfilling their manly duties within the family by being away from home.

As the performance of masculinity involved exercising the male right to exchange of women as sexual objects, then the Neapolitan men offered local women as an alternative to the lack of locally available Senegalese women. However, this offer was highly ambiguous and laden with risk. This was a line that the Senegalese men knew they shouldn't cross in order to maintain a complicit truce with their Neapolitan interlocutors. Both Ibra and Samba negotiated this by explaining that sex outside marriage was harām, or forbidden to them on religious grounds. The response of the Neapolitans was to emasculate them by accusing them of being gay. In the episode detailed above, Mimmo took things further and physically grabbed hold of Ibra whilst he was bent over, threatening to punish him, ostensibly by raping him. The projected rape of a straight man by another straight man constituted a more complex form of control than if Mimmo were gay or Ibra were a woman. Such ritualised insults served to undermine and intimidate Senegalese men along the pavement by putting them in the difficult position of having to prove a heterosexual masculinity whilst avoiding the spectre of miscegenation.

Neapolitan women passing by on the pavement repeatedly elicited these episodes of violent and barely manageable banter between the Neapolitan men and the Senegalese street vendors I was working with. One evening a Neapolitan woman walking down the road clearly caught the eye of the men whom she passed. Salvatore muttered to me darkly, "If she decides to get with a black man who hasn't seen a woman for years ... well you know that they really need to do fiki fiki!' On another afternoon, a Neapolitan woman walked past Ibra's stall wearing bright pink leopard-print leggings and a tight black top. Salvatore commented to me, 'Look how all the blacks are watching her.' A young Senegalese street vendor made a face at Salvatore and, indicating Ibra, who had lowered his gaze as the woman passed by, pulled on his left earlobe with his index finger and thumb. This homophobic Neapolitan gesture was meant to indicate that Ibra didn't look at the woman because he was gay. Both men laughed and Salvatore commented, 'All the men are looking, except Ibra. Ibra doesn't look at women. Ibra doesn't do fiki fiki.' The young Senegalese man came over to continue bantering with Salvatore and Salvatore asked him, 'Do you like women?' The young man looked awkward and started saying, 'Nooo', hesitantly. Salvatore immediately snapped back with 'So you're ...' - starting to lift his hand to his left ear. The young man quickly responded, 'OK yes!' Salvatore congratulated him and they both laughed amicably. 
Grotesque and darkly funny banter and catcalling raised questions about the status of women, migrant men and racial intimacy. It played an important role in the constitution of pavement life in Neapolitan street markets. Like the ways in which people talked about talk in the previous chapter, this was a key part of everyday negotiations of difference and belonging. These verbal styles and ritualistic games embodied locally hegemonic, masculine performances that integrated markers of race, ethnicity and class. They formed the social space of the pavement around notions of morality, kinship and economic entitlement that bolstered the political economy of sexual conventions in the city. Edgy humour was central to the ways in which this violent language was partially resisted by migrants working in street markets: it defused tensions and allowed them to make claims for inclusion in local hierarchies of masculinity. Yet humour also exacerbated tensions and acted in complicity with the oppression of other, more vulnerable people. It didn't stop migrant men from being vulnerable to the everlurking threat of violence, and mostly excluded migrant women who attempted to participate. These depressing displays of masculine prowess raised the spectre of people's humanity being up for question, something that remained negotiable in the street markets, but not so much elsewhere as antimigrant politics ramped up and policies designed to stop more people from making it to Europe were rolled out across the Mediterranean.

\section{Note}

1 Mario and Nicolardi (1944). 'Tammuriata' means the drumming of tambourines, which are the rhythmic base of this traditional southern Italian folk genre. 